\title{
Appendix Neuroendocrine Tumor cM1 TNM Finding v8
}

National Cancer Institute

\section{Source}

National Cancer Institute. Appendix Neuroendocrine Tumor CM1 TNM Finding v8. NCI

Thesaurus. Code C135134.

Appendix neuroendocrine tumor with distant metastasis. (from AJCC 8th Ed.) 